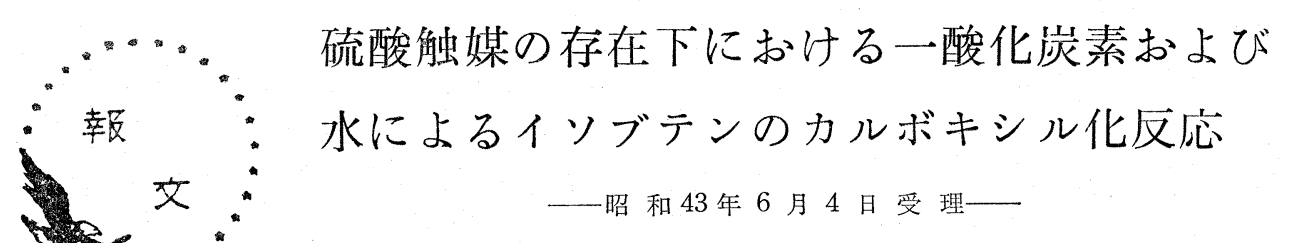

北海道立工業試験場 松 原睦 哉 北海道大学工学部 佐々木 誠・青村 和夫 大塚 博

\section{1. 緒言}

炭化水素からの工業用脂肪酸の合成については従来 強い関心がもたれ，パラフィン類の空気酸化，オキソ アルデヒドの酸化，金属カルボニル触媒によるオレフ ィンからの合成などの研究が行なわれている。さらに 近年, H. Koch ら ${ }^{1)}$ にり, 無機酸を触媒としオレフィ ン，一酸化炭素および水から第三級脂肪酸を主生成物 とする分枝脂肪酸が比較的温和な条件で合成されるこ とが見出されている。この第三級脂肪酸のエステルは 合成潤滑剂, 可塑剤, 乳化剂に, また金属塩はペイント 添加剤などとして種々の特性をもち ${ }^{2 \sim 4)}$, さらに新し い用途の開発が期待されている。K. E. Möller は種々 の直鎖および分枝の脂肪族，脂環族オレフィン，アル コール，不飽和脂肪酸などを濃硫酸あるいはそれ以外 の無機酸 ・ 三フッ化ホウ素錯合体を触媒とし，0 $70^{\circ} \mathrm{C} ， 1 \sim 100 \mathrm{~kg} / \mathrm{cm}^{2}$ の一酸化炭素圧下で第二級あ るいは第三級脂肪酸を合成する方法について報告して

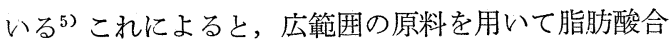
成が試みられているが, 触媒の濃度などの反応条件と オレフィンの反応性などについては詳細な報告は現在 まで見当たらない。著者らは硫酸触媒によりイソブテ ンよりトリメチル酢酸などの分枝脂肪酸を合成すると きの種々の反応条件が脂肪酸収率などに与える影響を 検討した。

\section{2. 実 験}

\section{2-2 原料イソブテンおよび一酸化炭素}

イソブテン：成型ベントナイト触媒により $300^{\circ} \mathrm{C}$ で tert-ブタノールを脱水し，生成ガスをシリカゲル，モ レキュラーシーブなどで乾燥後, 固体炭酸で冷却液化 してボンベに充填した。ガスクロマトグラフィーによ る分析の結果, 組成はイソブテン $98.8 \%$, イソブタン $0.1 \%$ ，空気 $1.1 \%$ (vol. ) (ただし，イソブテンとイ ソブタンの相対感度は同じとして計算した)であつた。 また，この場合のガスクロマトグラフィーによつては
イソブテンと 1-ブテンが分離されない可能性もある ので, 赤外線吸収スペクトル分析も行なつたが Sadtler のイソブテンの標準スペクトルと一致した。

一酸化炭素：炭酸ガスを約 $1100^{\circ} \mathrm{C}$ の木炭層中で還 元し, 生成ガスを $35 \%$ 水酸化カリウム水溶液で洗浄 し, ボンベに充填した。生成ガスの組成は CO $\mathrm{N}_{2} 2.1, \mathrm{O}_{2} 0.6, \mathrm{CO}_{2} 0.6, \mathrm{H}_{2} 5.2 \%$ (vol.) であつ た。原料ガス中の水素はイソブテンのカルボキシル化 に大きな影響はないと考えた。

\section{2-2 実験装置および操作法}

反応器は電磁上下かきまぜ式オートクレーブ (SUS 32 , 内容積 $300 \mathrm{ml}$ ) を用い, 上下かきませ回数は 60 回 /min であつた。反応温度は電気炉あるいは水槽によ り一定温度を保つよら調節した。

オートクレーブ中に硫酸触媒（条件により $n$-ヘキ サンを溶媒として加えた）を入れ，反応圧力 $50 \mathrm{~kg} /$ $\mathrm{cm}^{2}$ 以下のときは, 一酸化炭素初圧を $20 \mathrm{~kg} / \mathrm{cm}^{2}$ と し, 反応圧力 $50 \mathrm{~kg} / \mathrm{cm}^{2}$ 以上のときは初圧をまず $50 \mathrm{~kg}$ $/ \mathrm{cm}^{2}$ とした*。反応温度に達した後，ボンベより耐圧 液量計に移されたイソブテンを窒素による背圧によ り，所定量をオートクレーブ中へ導入し，できるだけ 所定反応圧力になるよう一酸化炭素を供給し，上下の かきまぜを始めた。反応により一酸化炭素が吸収され ると適時補給し，一定圧力を保つよう調節した。

\section{2-3 反応生成物の処理および分析}

オートクレーブより取り出された生成物は, 全量を 分液漏斗中で静置した。 $n$-ヘキサンを溶媒として用 いたときは,この後, Fig. 1 に示すように硫酸触媒層 と溶媒へキサン層を分離し，それぞれの層から，同じ 方法で生成脂肪酸とその他の有機油状生成物を抽出, 分離した。また, 溶媒 $n$-ヘキサンを用いないときは, オートクレーブよりの取り出し全量を Fig. 1 に示す

*実験に用いたガラス製液量計の耐圧度に制限され た。 


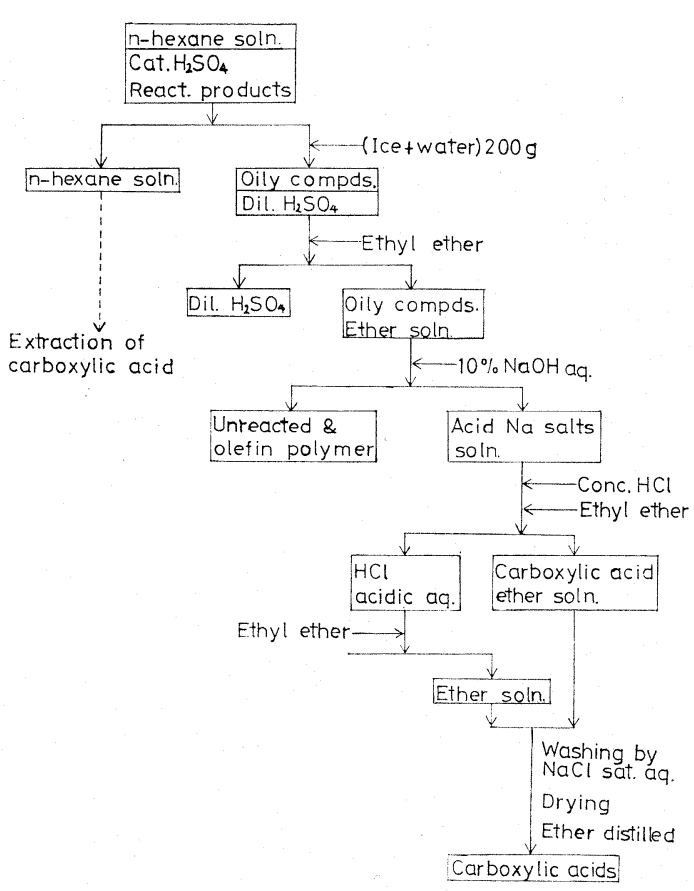

Fig. 1 The procedure for treatment of the reaction products, where $n$-hexane was used as the solvent.

ような硫酸触媒層の処理法と同じ方法で生成脂肪酸と その他の生成物に分離した。また，生成脂肪酸混合物 の酸価およびトリメチル酶酸含有率を測定した。トリ メチル酢酸含有率洴熱伝導度型ガスクロマトグラフィ 一により，つぎの条件で測定した。

カラム : Silicon DC550, 3. $0 \mathrm{~mm} \phi \times 3 \mathrm{~m}$

温 度 : $160^{\circ} \mathrm{C}$, ヘリウム $: 30 \mathrm{ml} / \mathrm{min}$

\section{3. 実験結果および考察}

3-1 イソブテン導入速度の影響

イソブテンは硫酸触媒中では第 3 級ブチルカルボニ ウムイオンとなり, これに一酸化炭素が付加してアシ ルイオン, さらに水の付加, プロトンの脱離によりト リメチル酶酸が生成すると考えられる。これを反応式 で示すと，つぎのようになる。

$$
\begin{aligned}
& \underset{\mathrm{CH}_{3}}{\mathrm{CH}_{3}}>\mathrm{C}=\mathrm{CH}_{2} \stackrel{\mathrm{H}_{2} \mathrm{SO}_{4}}{\longrightarrow} \underset{\mathrm{CH}_{3}}{\mathrm{CH}_{3}}>\stackrel{+}{\mathrm{C}}-\mathrm{CH}_{3} \\
& \underset{\mathrm{CH}_{3}}{\mathrm{CH}_{3}}>\stackrel{+}{\mathrm{C}}-\mathrm{CH}_{3}+\mathrm{CO} \longrightarrow \underset{+}{\mathrm{CH}_{3}}>\underset{+}{\mathrm{CO}} \underset{+}{\mathrm{CH}}-\mathrm{CH}_{3}
\end{aligned}
$$



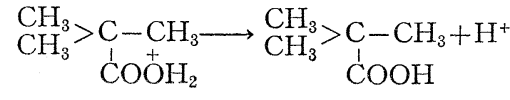

(TMA)

しかし，この式に示される反応と同時に，一方では tert-ブチルカルボニウムイオンはイソブテンとカチオ ン重合, さらに不均化などの副反応を起こすため, 生 成する脂肪酸はトリメチル酥酸以外に種々の炭素数の 脂肪酸を含む混合物である。酸性触媒によるオレフィ ンの重合反忘は一般にオレフィンに関しては二次であ るから，トリメチル酶酸生成の選択率におよぼす重合 の影響は大きい。そこで耐圧液量計よりオートクレー ブへ一定時間ごとに圧入するイソブテン量を変化さ せ，生成トリメチル酢酸量におよぼす影響を検討し た。一酸化炭素の反応による吸収は，イソブテン所定 量がオートクレーブ中へ圧入され終わつた後約 10 分 で認められなくなるので, 反応時間を（イソブテン全 量の圧入時間 +30 分）とした。また， $96.0 \%$ 硫酸 $184.0 \mathrm{~g}$ ，イソブテン圧入全量は $14.9 \mathrm{~g} \quad(0.27 \mathrm{~mol})$ 一酸化炭素反応圧力 $25 \mathrm{~kg} / \mathrm{cm}^{2}$. 一定とし, 反応後, 触媒を分離した後の生成物全量中のトリメチル酶酸含 有率を測定した。また，これから，導入イソブテン量 に対するトリメチル酶酸 (TMA) の収率* を算出し これらの結果を Table 1 亿示す。この表中に, イソブ テンの導入速度を $\mathrm{g} / \mathrm{min}$ の単位で示したが，これは 一定時間ごとに圧入されたイソブテン量で示され，た とえば, $0.6 \mathrm{~g} / 10 \mathrm{~min}$ は 10 分ごとにイソブテン $0.6 \mathrm{~g}$ をオートクレーブへ圧入したことを示している。これ らの結果から，一定時間ごとに圧入されるイソブテン 量の少ないほど，生成物中のトリメチル酶酸含有率は 大きく，また，トリメチル酶酸収率も大きい。圧入時 間間隔を小さくし，一度のイソブテン圧入量を少なく すると, トリメチル酶酸収率, すなわち, 選択率の増 加することが認められた。導入速度を $14.9 \mathrm{~g} /$ inst, で示してあるのは，所定反応条件に達したところで一 度にイソブテン全量 $(14.9 \mathrm{~g})$ を圧入した場合で, ト リメチル酶酸収率が低い。このカルボキシル化の律速 段階は触媒中に溶解した一酸化炭素のカルボニウムイ オンへの付加であると考えられるから ${ }^{6)}$ ，一定時間ご とに圧入されるイソブテン量が大きいとイソブテン濃 度が増加し, 前述のような副反応が進み, トリメチル 酢酸含有率が減少すると考える。

*式で示すと

トリメチル酶酸 (TMA) 収率 TMA生成量 $(\mathrm{g})$

= $\frac{\text { 遒入イソブテン量 }(\mathrm{g})}{\mathrm{T}} \times 100(\mathrm{wt} \%)$ 
Table 1 Effect of charging rate of $i-\mathrm{C}_{4} \mathrm{H}_{8}$

Conditions of carboxylation; Cat. $\mathrm{H}_{2} \mathrm{SO}_{4}: 96.0 \% 184 \mathrm{~g}$, Total weight of iso- $\mathrm{C}_{4} \mathrm{H}_{8}: 14.9 \mathrm{~g}$, Pressure of $\mathrm{CO}: 25 \mathrm{~kg} / \mathrm{cm}^{2}$

\begin{tabular}{|c|c|c|c|c|c|c|}
\hline \multirow{2}{*}{$\begin{array}{l}\text { Charging rate } \\
\left.\text { of } i-\mathrm{C}_{4} \mathrm{H}_{8}{ }^{a}\right) \\
(\mathrm{g} / \mathrm{min})\end{array}$} & \multicolumn{2}{|c|}{ Reaction } & \multirow{2}{*}{$\begin{array}{l}\text { Weight of } \\
\text { products } \\
\text { (g) }\end{array}$} & \multicolumn{3}{|c|}{$\mathrm{TMA}^{d)}$} \\
\hline & $\begin{array}{l}\text { Timer) } \\
(\min )\end{array}$ & $\begin{array}{c}\text { Temperature } \\
\left({ }^{\circ} \mathrm{C}\right)\end{array}$ & & $\begin{array}{c}\text { Content } \\
(w t \%)\end{array}$ & $\begin{array}{c}\text { Weight } \\
\text { (g) }\end{array}$ & $\begin{array}{r}\text { Yield } \\
(w t \%)\end{array}$ \\
\hline $0.6 / 10$ & 240 & 17 & 16.6 & 31.8 & 5.3 & 35.5 \\
\hline 1. $2 / 10$ & 140 & 18 & 15.9 & 27.7 & 4.4 & 29.7 \\
\hline 2. $4 / 10$ & 70 & 16 & 15.2 & 19.5 & 3.0 & 19.6 \\
\hline 1. $2 / 5$ & 70 & 17 & 16.3 & 25.5 & 4.2 & 27.9 \\
\hline $14.9 /$ inst $^{b)}$ & 120 & 18 & 15.2 & 15.6 & 2.4 & 16.0 \\
\hline
\end{tabular}

a) iso-butene was charged into the autoclaue at constant time intervals. For example " $0.6 \mathrm{~g} / 10 \mathrm{~min}$ " means that $0.6 \mathrm{~g}$ of $i$-butene was charged at $10 \mathrm{~min}$ intervals.

b) $14.9 \mathrm{~g}$ of $i s o$-butene was charged very rapidly into the autoclave at the beginning of reaction.

c) This reaction time is the sum of charging time of $i$-butene and reaction time after the charging of $i$-butene.

d) TMA : Trimethyl acetic acid.

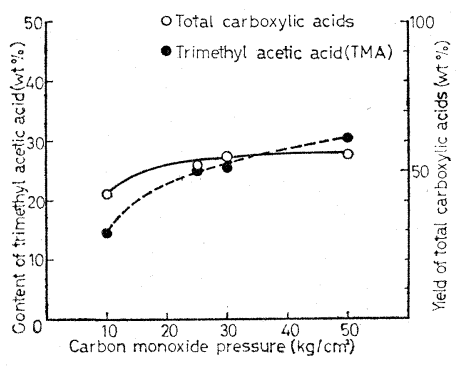

Reaction conditions;

Catalyst $\mathrm{H}_{2} \mathrm{SO}_{4}: 96 \%$ (184. $0 \mathrm{~g}$ )

iso-butene : $14.9 \mathrm{~g}$

Reaction temperature : $12 \sim 14^{\circ} \mathrm{C}$

Charging rate of iso-butene $: 1.2 \mathrm{~g} / 10 \mathrm{~min}$

Reaction time : $150 \mathrm{~min}$

Fig. 2 Relation between the Carbon monoxide pressure and the yield of total acid or content of TMA

\section{3-2 一酸化炭素圧の影響}

一酸化炭素圧が脂肪酸収率および脂肪酸中のトリメ チル酢酸含有率におよぼす影響について検討するた め, $96.0 \%$ 硫酸 $184.0 \mathrm{~g}$, 全導入イソブテン量 $14.9 \mathrm{~g}$ を 10 分間ごとに $1.2 \mathrm{~g}$ の導入速度でオートクレーブ中 へ圧入し，全反応時間を 150 分として，一酸化炭素圧 $10 \sim 50 \mathrm{~kg} / \mathrm{cm}^{2}$ の範囲で反応を行なつた。その結果を Fig. 2 に示す。これから，一酸化炭素圧の大きいほ
ぞ，生成脂肪酸中のトリメチル酢酸含有率，すなわち 単量体酸の選択率の大きいことが認められた。また全 脂肪酸収率* は $10 \mathrm{~kg} / \mathrm{cm}^{2}$ から $25 \mathrm{~kg} / \mathrm{cm}^{2}$ ではわずか 増しているが，それ以上 $50 \mathrm{~kg} / \mathrm{cm}^{2}$ ，の範囲ではほぼ 同じであつた。トリメチル酢酸含有率が増すのは，前 述のように，このカルボキシル化の律速段階が一酸化 炭素のカルボニウムイオンへの付加反応であり，した がつて一酸化炭素圧の高いほど，この反応速度は大と なり，また生成した脂肪酸の tert-ブチルアシルイオ ンあるいはカルボニウムイオンへの脱カルボニル反応 （逆反応）さらに二次的な重合，不均化などの反応が 抑えられるためと考えられる。

3-3 溶媒 $n$ ーヘキサノンの影響

イソブテンの強酸性触媒によるカルボキシル化反応 の場合，副反応としてイソブテンの重合および不均化 反応が同時に進むため, 溶媒を用いることにより全脂 肪酸収率やイソブテンから単量体酸であるトリメチル 酢酸生成の選択性が変化すると考えられる。ここで

* 全脂肪酸収率とは, イソブテンに直接一酸化炭素 および水が付加してトリメチル酢酸を生成する反応

$\left(\mathrm{CH}_{3}\right)_{2} \mathrm{C}=\mathrm{CH}_{2}+\mathrm{CO}+\mathrm{H}_{2} \mathrm{O} \longrightarrow\left(\mathrm{CH}_{3}\right)_{3} \mathrm{C}-\mathrm{COOH}$

にっいて，使用したイソブテン量から TMA の化学 量論的生成量を求め，これを基礎に算出した生成脂肪 酸の収率 $(w t \%)$ である。すなわち 全脂肪 $(\mathrm{wt} \%)=\frac{\text { 全生成脂肪酸量 }(\mathrm{g}) \times 100}{\text { 導入イソブテン量 }(\mathrm{mole}) \times 102.1}$ (102.1=トリメチル酢酸の分子量) 
Table 2 Effect of $n$-hexane Solvent

Conditions of carboxylation; Cat. $\mathrm{H}_{2} \mathrm{SO}_{4}: 96.0 \%$, Pressure of $\mathrm{CO}: 80 \mathrm{~kg} / \mathrm{cm}^{2}$ Reaction time : $150 \mathrm{~min}$.

\begin{tabular}{|c|c|c|c|c|c|c|c|c|c|}
\hline \multirow[b]{2}{*}{$\begin{array}{l}\text { Exp. } \\
\text { No. }\end{array}$} & \multirow[b]{2}{*}{$\begin{array}{l}\mathrm{H}_{2} \mathrm{SO}_{4} \\
\text { weight }\end{array}$} & \multirow[b]{2}{*}{$\begin{array}{l}n \text {-hexane } \\
\text { weight }\end{array}$} & \multirow[b]{2}{*}{$\begin{array}{l}i \text {-butene } \\
\text { weight }\end{array}$} & \multirow{2}{*}{$\begin{array}{l}\frac{n \text {-hexane }}{i \text {-butene }} \\
\text { mole ratio }\end{array}$} & \multicolumn{4}{|c|}{ Carboxylic acids } & \multirow[b]{2}{*}{$\begin{array}{l}\text { Rate of } \\
\text { Carboxylation }\end{array}$} \\
\hline & & & & & weight & Yield & $\begin{array}{c}\text { acid } \\
\text { value }\end{array}$ & & \\
\hline 2 & $\begin{array}{r}(\mathrm{g}) \\
200.5\end{array}$ & $\begin{array}{l}(\mathrm{g}) \\
83.2\end{array}$ & $\begin{array}{l}(\mathrm{g}) \\
26.7\end{array}$ & 2.03 & $\begin{array}{l}(\mathrm{g}) \\
18.1\end{array}$ & $\begin{array}{r}(w t \%) \\
37.3\end{array}$ & 388 & $\begin{array}{c}(\mathrm{mol}) \\
0.13\end{array}$ & $\begin{array}{l}\text { (mol\%) } \\
26.2\end{array}$ \\
\hline 3 & 184.5 & 55.4 & " & 1. 34 & 31.7 & 65.3 & 384 & 0.22 & 45.5 \\
\hline 6 & 180.8 & 33.0 & " & 0.80 & 28.2 & 58.0 & 416 & 0.21 & 43.8 \\
\hline 8 & 182.8 & 16.5 & " & 0.40 & 22.2 & 45.7 & 388 & 0.15 & 32.3 \\
\hline 7 & 182.4 & 0 & "I & 0 & 17.0 & 35.0 & 319 & 0.10 & 20.3 \\
\hline 11. & 91.8 & 41.6 & 13.4 & 2.03 & 14.6 & 60.1 & 365 & 0.10 & 39.9 \\
\hline 15 & 92.1 & 27.7 & " & 1. 35 & 15.9 & 65.3 & 369 & 0.11 & 43.4 \\
\hline 13 & 91.5 & 16.5 & " & 0.81 & 14. 2 & 58.2 & 354 & 0.09 & 37.5 \\
\hline 14 & 137.8 & 18.8 & 20.1 & 0.40 & 19.7 & 54.0 & 390 & 0.14 & 38.3 \\
\hline
\end{tabular}

は，nーヘキサンを溶媒として用いたとき，溶媒がイ ソブテンのカルボキシル化におよぼす影響について検 討した。反応は, 一酸化炭素反応圧 $80 \mathrm{~kg} / \mathrm{cm}^{2}$, 反応 温度 $15 \sim 20^{\circ} \mathrm{C}$, 反応時間 150 分および 60 分の条件で, $96.1 \%$ 硫酸 $50 \sim 100 \mathrm{ml}$, イソブテン $13.4 \sim 26.7 \mathrm{~g}$, $n$-ヘキサンを $0 \sim 126 \mathrm{~m} l$ の範囲で変化させた。イソ ブテンは反応初期に全量を一度にオートクレーブ中に 圧入した。実験結果を Table 2 に示す。この Table 2 の中の Exp. No. $2 \sim 8$ に示されるように, 内容積 $300 \mathrm{~m} l$ の反応容器で, この反応条件では, $n$-ヘキサ ン $80 \mathrm{~m} l$ 前後で全脂肪酸収率は最大であつた。これを n-ヘキサン量のイソブテン量に対するモル比で示す と, 1.34 である。しかし， $n$-ヘキサン添加量がさら に増寸と, 全脂肪酸収率が減少するのは, 用いた反応 器（オートクレーブ）の内容積による制約や上下かき まぜによる一酸化炭素と濃硫酸との接触効果が逆に低 下し，硫酸層中への一酸化炭素の溶解あるいは拡散が 妨げられ，また同時に，触媒量が相対的に減少し， tert-ブチルカチオンおよび他のカルボニウムイオンの 安定性が減少するためと考えられる。この点を検討す るため, イソブテン, 溶媒および硫酸量を減らし, 反 応時間を60分とし，おのおのの重量比を前の実験と同 じように変化させ,反応を行なつた。この結果を Table 2 の後半 Exp. No. 11 15 に示す。

この結果からもわかるように, 全脂肪酸収率は, $n$-ヘキサン/イソブテン (モル比) $=1.35$ 付近で最も 大きく，これ以上の $n$-ヘキサン量で収率は減少して いる。この傾向は前の条件で得られた実験結果と同し であるが，収率の低下の程度が小さい。また，原料イ
ソブテン量に対する一酸化炭素, 水の付加 (Carboxylation）の反応率を, 生成脂肪酸中のカルボキシル基 の全モル数から次式により算出し, Table 2 中に示し た。

カルボキシル化反応率 $(\mathrm{mol} \%)$

$=[$ (酸価) (生成脂肪酸量) / /56.1(イソブテン量 $\mathrm{mol}$ )

$$
\times 1000] \times 100
$$

$=[$ カルボキシル基 $\mathrm{mol} /$ イソブテン $\mathrm{mol}] \times 100$.

この結果からも, 上の反応条件で, $n$-ヘキサン/イ ソブテン (モル比) $=1.35$ 付近のとき, カルボキシル 化反応率が最も大きいことが認められた。

イソブテンからのこの脂肪酸合成反応は, 前述した ように，濃硫酸中で tert-ブチルカチオンあるいは他 のカルボニウムイオンに, 溶解した一酸化炭素が付加 する段階が律速であると考えられている。いま,一酸 化炭素の濃硫酸および $n$-ヘキサンへの溶解度を比較

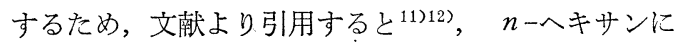
ついては Data がないが，n-ヘプタンについては， $25^{\circ} \mathrm{C}, \alpha=0.286\left[\operatorname{COm} l\left(760 \mathrm{~mm} 25^{\circ} \mathrm{C}\right) / n\right.$-heptane $\mathrm{m} l$ (760mm CO)], また $95.6 \%$ 硫酸については, $25^{\circ} \mathrm{C}$, $\alpha=0.0216$ である。したがつて， $n$-ヘプタンのほう が一酸化炭素の溶解度は大きい, また， nーヘキサン についても, これと比較し, 大きな差違はないと推定 される。反応は一酸化炭素も含め全圧 $80 \mathrm{~kg} / \mathrm{cm}^{2}$ で行 なつているから，高圧による Henry の法則からのか たよりはあるとしても，n一ヘキサンのほらが濃硫酸 より溶解度は大きいと考えられる。したがつて, $n$ ヘキサンの添加によつて, イソブテンは稀釈され, 重 
Table 3 Effect of the reaction temperature on the yield of total acids, content of TMA and acid value

Reaction temperature $\left({ }^{\circ} \mathrm{C}\right)$

$$
4
$$

18

93

\begin{tabular}{rlrr}
\multicolumn{4}{c}{ Total carboxylic acids } \\
\hline weight & yield & TMA content & acid value \\
$(\mathrm{g})$ & $(\mathrm{wt} \%)$ & $(\mathrm{wt} \%)$ & \\
30.2 & 62.7 & 19.5 & 343.3 \\
24.2 & 49.7 & 23.1 & 366.5 \\
6.3 & 12.0 & 70.9 & 453.0
\end{tabular}

合などの副反応がおさえられると同時に，一酸化炭素 の液相中への溶解度の増加により，tert-ブチルカチオ ンおよびその他のカルボニウムイオンへの一酸化炭素 の付加が速くなるため, イソブテンのカルボキシル化 反応率が増加すると考えられる。また, 溶媒 $n$ 一へキ サン量が少なくなるとイソブテンとカルボニウムイオ ンとの重合あるいは不均化反応が速くなり重合による 脂肪酸の量が増すと考えられる。

以上の結果から， $n$-ヘキサンを適当量添加するこ とによりイソブテンのカルボキシル化反応率を向上さ せることができると考える。

\section{3-4 反応時間の影響}

反応時間が脂肪酸収率およびトリメチル酢酸含有率 におよぼす影響について検討した。反応は，一酸化炭 素圧 $50 \mathrm{~kg} / \mathrm{cm}^{2}$, 反応温度 $15 \sim 20^{\circ} \mathrm{C}$ ，触媒硫酸 $96 \%$ $100 \mathrm{~m} l(183.0 \mathrm{~g})$, 溶媒 $n$-ヘキサン $100 \mathrm{~m} l$, イソブテ ン $26.7 \mathrm{~g}$ の条件下で, イソブテン全量を最初に圧入 し，その後の反応時間を 10 300 分の範囲で変化させ た。この結果を Fig. 3 に示す。

この結果から，反応時間が長いほど，脂肪酸収率は 増すが, 150 分以上でほぼ一定值を示し, トリメチル 酢酸含有率は時間とともに減少していて，とくに反応 開始後 1 時間までの 減少率が大きい。また Fig. 3 に 生成脂肪酸中のカルボキシル基のモル数の変化も示し た。この結果, 反応時間 150 分までわずかカルボキシ ル基が増しているが全体で大きな変化はない。これら の結果から, 一度生成したトリメチル酢酸（硫酸触媒 中では $\mathrm{RCOOH}_{2}{ }^{+}$および $\mathrm{RCO}^{+} \ldots . . . \mathrm{HSO}_{4}{ }^{-}$の形で存 在していると考えられる7)）の一部が逆方向の反応で 一酸化炭素を脱離し, tertーブチルカルボニウムイオン となり，さらに重合および重合して生じたカルボニウ ムイオンの不均化反応を経て, ふたたび一酸化炭素が 付加し種々の高級脂肪酸を生成すると考えられる。こ れは, Meinwald ら ${ }^{8)}$ が硫酸中に执いて $\alpha$-cinenic acid から geronic acid への異性化を説明した Decarbonylation-Recarbonylation Mechanism功も充

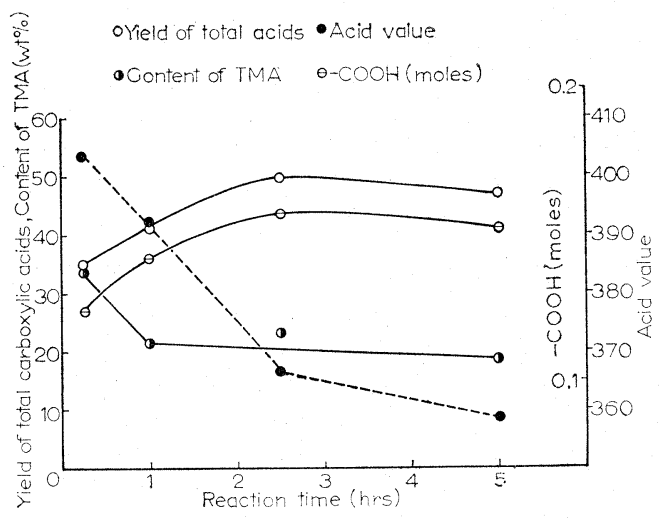

Fig. 3 Effect of reaction time on the yield of total acids, content of TMA and acid value of total acids

分推察できる。

\section{3-5 反応温度の影響}

共通反応条件は, イソブテン $26.7 \mathrm{~g}$, 溶媒 $n$-ヘキ サン $100 \mathrm{~m} l$, 硫酸 $(96.0 \%) 100 \mathrm{~m} l(183.0 \mathrm{~g})$, 一酸 化炭素圧 $50 \mathrm{~kg} / \mathrm{cm}^{2}$, 反応時間 150 分で, イソブテン は一定反応条件に達した後, 一度に全量圧入した。温 度を $4 \sim 93^{\circ} \mathrm{C}$ 範囲で変化させた。この結果を Table 3 に示す。これから,この温度範囲では低温ほど脂肪 酸収率は大きいが, 脂肪酸の酸価および生成脂肪酸中 のトリメチル䣷酸含有率は高温度において大きい。こ の反応では,イソブテンより種々の副反応を伴い, 種々 の炭素数の脂肪酸が生成するが, 低温では,これら重合 などの副反応による高分子量のオレフィンよりのカル ボニウムイオンあるいはアシルイオンが tert-ブチル カルボニウムイオンとともに安定であるため脂肪酸収 率が大きいが, $90^{\circ} \mathrm{C}$ 前後では,イソブテンの二量化など によるオクテンなどが解重合し,かつ tert-ブチルカル ボニウムイオンが比較的安定であるので, 全酸収率は 減少するが，TMA 含有率が増加すると考えられる。 しかしトリメチル酢酸は濃硫酸中 $105 \sim 110^{\circ} \mathrm{Cで}$ 分解す ると報告されている ${ }^{9)}$ ので, 反応温度が $100^{\circ} \mathrm{C}$ 以上に 


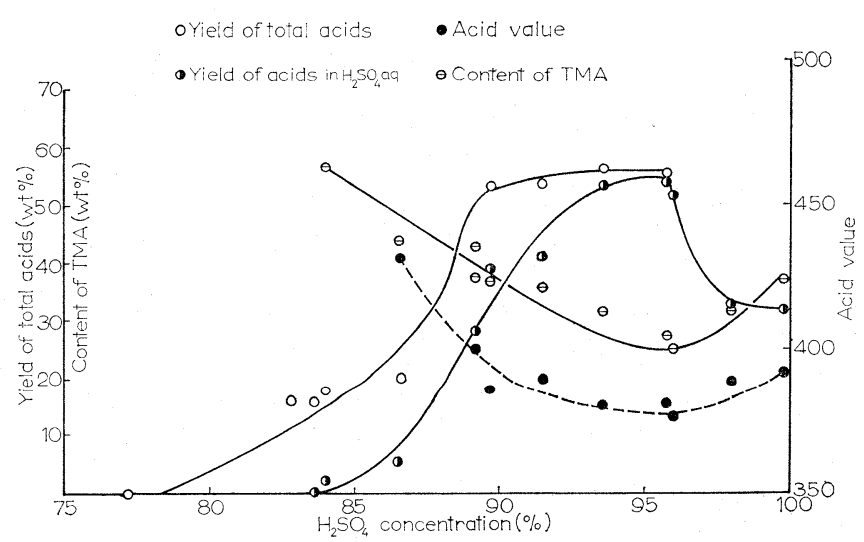

度に関係なくほぼ一定で，触媒硫酸中の 脂肪酸が硫酸濃度の減少とともに減少 し， $84 \%$ 以下 $80 \%$ までの範囲では $n$-へ キサン相においてのみ脂肪酸が存在する ことが認められた。また，Fig. 4 亿示す ように, 生成脂肪酸中のトリメチル酶酸 含有率については，触媒硫酸中より抽出 した脂肪酸中のトリメチル酶酸含有率 は，全脂肪酸収率の低下とともに堌加す る。したがつて触媒硫酸濃度の減少とと もに増加するが， $n$ 一ヘキサン相中より 抽出された脂肪酸中のトリメチル酢酸含 有率は，硫酸濃度に関係なく，ほぼ $2 \%$

Fig. 4 Effect of $\mathrm{H}_{2} \mathrm{SO}_{4}$ catalyst concentration on the yield of tolal acids, content of TMA, acid value of total acids and the yield of acids in $\mathrm{H}_{2} \mathrm{SO}_{4}$ aq, solution

なるとイソブテンよりの脂肪酸生成量はごく少量と考 えられる。

\section{3-6 触媒硫酸濃度および硫酸量の影響}

硫酸濃度の変化による $\mathrm{H}_{2} \mathrm{SO}_{4}-\mathrm{H}_{2} \mathrm{O}$ 系の組成につい ては，多くの報告があるが，ここでイソブテンのカル ボキシル化反応におよぼす硫酸濃度の影響について検 討した。共通の反応条件は，イソブテン $26.7 \mathrm{~g}$, 溶媒 $n$ 一ヘキサン $100 \mathrm{~m} l$, 一酸化炭素圧 $50 \mathrm{~kg} / \mathrm{cm}^{2}$, 反応時 間 150 分で種々濃度の硫酸 $100 \mathrm{ml}$ を用い，イソブテ ンは一定反応条件に達した後, 一度に全量圧入した。 温度は反応初期に上昇するが，硫酸濃度により最高温 度は異なり，その最高は $30^{\circ} \mathrm{C}$ であつた。実験結果を Fig. 4 亿示す。図でわかるように硫酸濃度約 90 ～96\% の範囲では，全脂肪酸収率はほとんど変化なく 50 ５5 $w t \%$ であつた。全脂肪酸収率流酸濃度が $90 \%$ 以下 で濃度の減少とと.もに減少し，また $96 \%$ 以上になると かえつて減少した。この全脂肪酸量とは，反応終了後 $n$ 一ヘキサン溶液と触媒相を分離し，この両者中から それぞれ抽出分離された脂肪酸の和である。Fig. 4 亿 おいて, 点線で示したのは, この硫酸触媒中より抽出 された脂肪酸のみについての収率である。以上の実験 結果から，触媒として用いた硫酸濃度が $93 \%$ 以上で は，オートクレーブより取り出された状態で，溶媒 $n$ 一ヘキサン相には脂肪酸はほとんど見出されず，濃 度 $93 \%$ 以下で溶媒中に脂肪酸が混入しはじめ，90 84 $\%$ の範囲では， $n$ ーヘキサン相中の脂肪酸量は硫酸濃
で， $82.8 \%$ の場合は $7 \%$ でわずか大きく，大部分は $\mathrm{C}_{9}$ などの重合，不均化を経て生成した脂肪酸である。 また Fig. 4 には，触媒硫酸中より分離された脂肪酸 の酸価も示したが，上のトリメチル酶酸含有率と同じ ように，含有率の増加とともに増している。Fig. 4 氻 ら, 硫酸濃度 $77.2 \%$ ではカルボキシル化反応は進まな いが，ほとんど水を含んでいない $99.8 \%$ 硫酸の場合に はカルボキシル化反応の進むことが認められた。また 95. 9\%硫酸を用い, 触媒硫酸量がイソブテンのカルボ キシル化反応におよぼす影響について検討した。共通 の反応条件は, イソブテン $26.7 \mathrm{~g}$, 溶媒 $n$ 一へキサン $100 \mathrm{~m} l$, 一酸化炭素圧 $50 \mathrm{~kg} / \mathrm{cm}^{2}$, 反応時間 150 分で, 反応温度はイソブテンを全量一度に圧入する反応初期 で， $25^{\circ} \mathrm{C}$ 位まで上昇するが，できるだけ $15 \pm 1{ }^{\circ} \mathrm{C}$ とな るように調節した。実験結果を Fig. 5 に示す。これ によると全脂肪酸収率はイソブテン $26.7 \mathrm{~g}$ に対して, $95.9 \%$ 硫酸を $70 \mathrm{~g}$ 以上使用したときはほぼ同じで，約 60wt\%であるが，これ以下では収率は減少している。 このらち, 溶媒 $n$ 一ヘキサン相より分離された脂肪酸 量は全脂肪酸量に対し $2.5 \sim 25.3 \%$ で, 触媒硫酸量の 増加とともに減少しており，そのトリメチル酢酸含有 率は $0 \sim 2 \%$ であるのに対し, 触媒硫酸中より分離さ れた脂肪酸収率は $28.6 \sim 57.0 \mathrm{wt} \%$ と触媒硫酸量の増 加とともに增し，またそのトリメチル酢酸含有率も Fig. 5 に示すように, 増している。つぎに, Fig. 4 , Fig. 5 の実験結果からイソブテンのカルボキシル化反 応を検討した。

種々の濃度の硫酸組成について, 多くの研究報告が あるが, Robertson らのデータ10) によると, 濃硫酸 中の遊離の水は微量で, 大部分はプロトンと水和した 形で存在し， $74.6 \%$ 以上では遊離の $\mathrm{H}_{2} \mathrm{SO}_{4}$ が存在し 93. $6 \%$ 以上では成分中最も多いとされている。いま, 
Table 4 Relation between the yield of total acids and the composition of cat. $\mathrm{H}_{2} \mathrm{SO}_{4}$

\begin{tabular}{|c|c|c|c|c|c|}
\hline \multicolumn{2}{|c|}{$\mathrm{H}_{2} \mathrm{SO}_{4}$} & \multicolumn{3}{|c|}{ Components/iso-butene (mole ratio) } & Yield of total acids \\
\hline $\begin{array}{c}\text { Concentration } \\
(\%)\end{array}$ & $\begin{array}{r}\text { weight } \\
(\mathrm{g})\end{array}$ & $\begin{array}{c}\text { free } \\
\mathrm{H}_{2} \mathrm{SO}_{4}\end{array}$ & $\mathrm{H}_{3} \mathrm{O}^{+}$ & $\mathrm{H}_{5} \mathrm{SO}_{5}^{+}$ & $(w t \%)$ \\
\hline 99.8 & 182.7 & & & & 32.0 \\
\hline 98.0 & 183.1 & 3.02 & 0.038 & 0.39 & 32.9 \\
\hline 96.0 & 182.9 & 2.75 & 0.60 & 0.24 & 51.7 \\
\hline 95.8 & 183.0 & 2.62 & 0.65 & 0.23 & 55.5 \\
\hline 93.6 & 182.5 & 2.18 & 1.18 & 0.13 & 56.1 \\
\hline 91.5 & 181.5 & 1.77 & 1.54 & 0.08 & 53.6 \\
\hline 89.7 & 182.0 & 1. 48 & 1.76 & 0.04 & 53.2 \\
\hline 89.2 & 180.8 & 1. 35 & 1.79 & 0.04 & 42.7 \\
\hline 86.6 & 178.0 & 0.96 & 1.84 & 0.02 & 20.1 \\
\hline 84.0 & 174.7 & 0.59 & 1.87 & 0.01 & 17.7 \\
\hline 83.6 & 175.0 & 0.53 & 1.86 & 0.01 & 15.8 \\
\hline 82.8 & 173.7 & 0.43 & 1.87 & 0.004 & 16.0 \\
\hline 77.2 & 169.8 & 0.36 & 1.25 & 0 & 0 \\
\hline 95.9 & 183.0 & 2.64 & 0.63 & 0.24 & 58.4 \\
\hline " & 91.5 & 1.32 & 0.32 & 0.12 & 60.6 \\
\hline " & 70.0 & 1.01 & 0.24 & 0.09 & 56.7 \\
\hline " & 45.8 & 0.66 & 0.16 & 0.06 & 38.2 \\
\hline
\end{tabular}

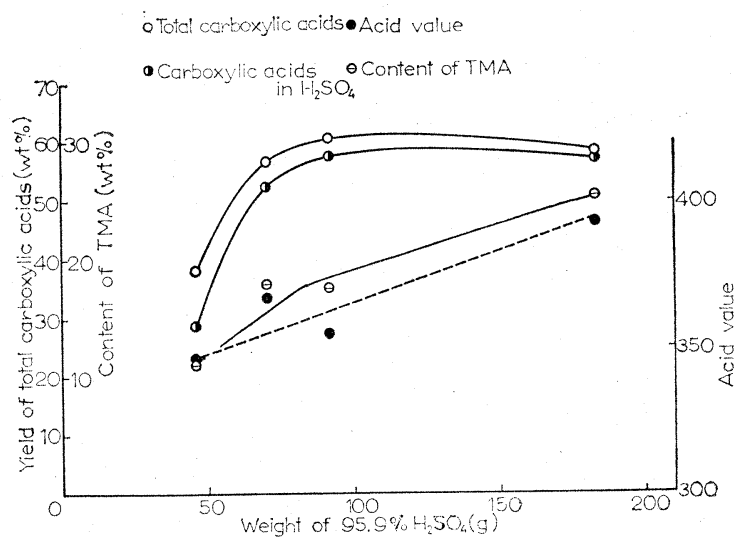

Fig. 5 Effect of $\mathrm{H}_{2} \mathrm{SO}_{4}$ catalyst weight on the yield of total carboxylic acids, content of TMA, acid value and the yield of acids in cat. $\mathrm{H}_{2} \mathrm{SO}_{4}$ aq. soln.

イソブテンのカルボキシル化反応の過程を観察する と, イソブテンの反応系への導入により，初期段階と して, 触媒中の遊離の $\mathrm{H}_{2} \mathrm{SO}_{4}$ あるいは $\mathrm{H}_{3} \mathrm{O}^{+}$と反 応して次式のよらにカルボニウムイオンを生成し $\left(\mathrm{CH}_{3}\right)_{2} \mathrm{C}=\mathrm{CH}_{2}+\mathrm{H}_{2} \mathrm{SO}_{4} \longrightarrow\left(\mathrm{CH}_{3}\right)_{2} \mathrm{C}+\mathrm{CH}_{3} \cdots \mathrm{HSO}_{4}^{-}$ あるいは $\left(\mathrm{CH}_{3}\right)_{2} \mathrm{C}=\mathrm{CH}_{2}+\mathrm{H}_{3} \mathrm{O}^{+}+\mathrm{HSO}_{4}^{-} \longrightarrow\left(\mathrm{CH}_{3}\right)_{2} \mathrm{C}+\mathrm{CH}_{3} \cdots$

$$
\mathrm{HSO}_{4}{ }^{-}+\mathrm{H}_{2} \mathrm{O}
$$

となるが,この $\mathrm{H}_{2} \mathrm{O}$ は硫酸中の過剩の遊離 $\mathrm{H}_{2} \mathrm{SO}_{4}$ により, すみやかに

$$
\mathrm{H}_{2} \mathrm{O}+\mathrm{H}_{2} \mathrm{SO}_{4} \leftrightarrows \mathrm{H}_{3} \mathrm{O}^{+}+\mathrm{HSO}_{4}^{-}
$$

となるものと考えられる。したがつて，反応系中 のカルボニウムイオンは $\mathrm{HSO}_{4}^{-}$とイオン対を形 成し, さらに直接一酸化炭素が付加するかあるい は,イソブテンが付加し，二量体化した後，一酸 化炭素が付加して一般に $\mathrm{RCO}^{+}+\ldots . . . \mathrm{HSO}_{4}{ }^{-}$を生 成し, さらに硫酸中の $\mathrm{H}_{3} \mathrm{O}^{+}$により大部分は $\mathrm{RCOOH}_{2}+$ となつて触媒相中に存在するものと考 えられる。したがつて, 硫酸中に未解離の $\mathrm{H}_{2} \mathrm{SO}_{4}$ が存在する濃度でカルボキシル化反応が進むと考 えられ, Robertson のデータによると,未解離の $\mathrm{H}_{2} \mathrm{SO}_{4}$ が存在するのは $74.7 \%$ 以上であり, 実験結果から, 脂肪酸の生成する濃度もほぼこれと一致している。い ま, Robertsonのデータから内插により, 使用した濃 度の硫酸の組成を計算し, 主成分について反応初期の 圧入イソブテン量に対するモル比で示すと Table 4 の ようになる。Table 4 の結果から，反応初期における 硫酸中の遊離の $\mathrm{H}_{2} \mathrm{SO}_{4}$ がイソブテンに対しモル比で 1 以上でほぼ同じ脂肪酸収率が得られることが認めら れた。しかし，96\%以上の硫酸濃度で脂肪酸収率がか えつて減少する理由は明らかでないが, 硫酸中の水和 
プロトンが減少し， $\mathrm{RCOOH}_{2}{ }^{+}$が減つて $\mathrm{RCO}^{+} \ldots \ldots$ $\mathrm{HSO}_{4}^{-}$- の形で存在するが, これは硫酸漂度により， その安定性が強く影響されるためと考えられる。また $93 \%$ 以下で $n$ 一ヘキ少ン相中より得られる脂肪酸量が 増すのは, 硫酸濃度の減少によってトリメチル酶酸よ りも高級な脂肪酸のプロトン和した $\mathrm{RCOOH}_{2}{ }^{+}$が $\mathrm{RCOOH}$ となりやすいため, 硫酸相から溶媒相へ移 動し，一方，プロトン和したトリメチル酢酸は硫酸濃 度が減少しても比較的安定に硫酸中に溶解しているも のと考えられる。

\section{4. 総括}

濃硫酸の存在下でイソブテンの一酸化炭素および水 によるカルボキシル化により分枝 $\mathrm{C}_{5}$ 脂肪酸 (トリメ チル酶酸) などを合成する反応について, 硫酸の濃度 および量, 反応温度, 一酸化炭素圧, 溶媒として使用 した $n$ 一ヘキサン量などの種々の反応条件が全脂肪酸 収率や生成脂肪酸中のトリメチル酶酸含有率におよぼ す影響について検討した。

装置には電磁上下攪拌式オートクレーブを使用し, 一酸化炭素加圧下で硫酸相中ヘイソブテンを圧入し反 応させた。反応生成物は氷水中一注がれ, 硫酸相と分 離し, カ性ソーダ水溶液で処理し, 脂肪酸成分を分離 した。

実験の結果は, 反応系に一度に導入するイソブテン が少ないほどトリメチル酶酸含有率は大きかつた。反 応圧力は 10 50kg/ $\mathrm{cm}^{2}$ の範囲で, 高圧ほぼトリメチ 儿酶酸含有率は大きく, 反応温度 $4 \sim 93^{\circ} \mathrm{C}$ の範囲内 では温度の低いほどカルボキシル化が有利に進行し た。また， $n$ 一へキサンを溶媒として用いることによ りカルボキシル化反応率を増すことができた。使用し た硫酸の裖度が $90 \%$ 以上でイソブテンのカルボキシル 化反応率が大きく，ほぼ一定の脂肪酸収率が得られた
が,77.5\%以下ではカルボキシル化は進まなかつた。ま た $98 \%$ 以上になると脂肪酸収率はかえつて減少した。 硫酸濃度 $93 \%$ 以下では, 硫酸層と溶媒層の両方に脂肪 酸が分布し, 硫酸濃度の減少とともに溶媒 $n$-ヘキサ ンで抽出される脂肪酸量が増加した。

（この報文の一部は日本化学会第19年会で発表した）

\section{文献}

1) H.Koch, Brnnstoff-Chem., 36, 321 (1955)

H. Koch, Fette, Seifen Anstrichmittel, 59 493 (1957)

2) W. J. Ellis and C. Roming, Hydrocarbon Processing, 44, No. 6, 139 (1965)

3) E. W. Duck, J.A. Waterman and G.E. Le Heij J.Appl. Chem., 12, 469 (1962)

4) R.W.F. Kreps, Fette, Seifen Anstrichmittel, 66, 1072 (1964)

5) K. E. Möller, Brennstoff-Chem., 45, 129 (1964)

6) Y. Takezaki et al., Bull. J.Pet. Inst., 8, 31 (1966)

7) N.C. Deno, C. V.Pittman, Jr., and M. J. Wisotsky, J.Am. Chem. Soc., 86, 4370 (1964)

8) J. Meinwald, H.C. Hwang, D. Christman and A. P. Wolf, J.Am. Chem, Soc., 82, 483(1960)

9) E. Campaigne and C. M. Suter, J. Am. Chem. Soc., 68, 880 (1946)

10) E. B. Robertson and H.B.Dunford, J.Am. Chem. Soc., 86, 5080 (1964)

11) International Critical Tables Vol. III, 260 (1928)

12) A Seidell, W.F. Linke, "Solubilities of Inorganic and Metal Organic Compounds" Vol.I, 453 (1958)

\title{
Carboxylation of Isobutene with Carbon Monoxide and Water in the Presence of Sulfuric Acid Catalyst
}

\author{
by Mutsuya Matsubara, \\ *Makoto Sasaki, *Kazuo Aomura and *Hiroshi Ohtsuka \\ (Hokkaido Industrial Research Institute, `Faculty of Engineering, Hokkaido University)
}

SYNOPSIS:--Carboxylation of 250 -butene with carbon monoxide and water to produce branched $\mathrm{C}_{j}$ acid (trimethyl acctic acid) as the main product was studied under various reaction conditions in the presence of concentrated sulfuric acid. The aim of this work was to observe 
the influence of reaction conditions, such as the catalyst acid concentration, and the amount of the catalyst, reaction temperature, the amount of the solvent ( $n$-hexane) etc, on the yield of carboxylic acids.

High carbon monoxide pressure favored carboxylation between $10 \mathrm{~kg} / \mathrm{cm}^{2}$ and $50 \mathrm{~kg} / \mathrm{cm}^{2}$, and the yield of carboxylic acids increased with the decrease of reaction temperature between 4 and $93^{\circ} \mathrm{C}$

Carboxylation was predominant under the sulfuric acid concentration of $90 \%$ and higher. However, the yield of carboxylic acids decreased under the acid concentration of $98 \%$ and higher, presumably due to the lack of water in the reaction zone which is necessary to stabilize the carboxylated intermediates. Under the acid concentration below $93 \%$, the produced carboxylic acids showed the increasing tendency to dissolve in $n$-hexane solvent with the decrease of the acid concentration. 